\title{
新技術 $の$
}

\section{テレビ用ローコスト $\mathrm{AD} / \mathrm{DA}$ コンバーター}

松 下 孟 史 $^{\dagger}$

ディジタルテレビ等, 民生機器のディジタル化を実現するには, ローコストのビデオ用 $\mathrm{AD} / \mathrm{DA}$ コンバーターが必須である. 新構想に基づいたローコスト $\mathrm{AD} / \mathrm{DA}$ コンバーターの開発について

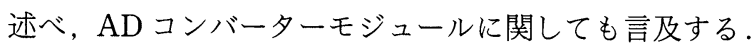

\section{1. まえがき}

オーディオ機器の分野では, すでにコンパクトディ スク, PCM ディジタルオーディオプロセッサ等, 民 生機器のディジタル化が実用化され，オーディオ界に 大きなインパクトを与えている1).一方, ビデオ機器 の分野では, 放送用機器や波形解析装置等, 計測機器 のディジタル化が進行しているとはいうものの, ディ ジタルテレビ2) 等, 民生機器のディジタル化に関して

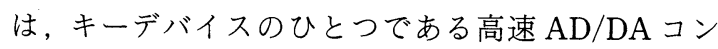
バーターが高価であるために，展開が阻害されてき た。

今回, 新構想に基づき, $30 \mathrm{MHz}$ で動作する新直並 列形 8 ビット $\mathrm{AD}$ コンバーター $(\mathrm{CX} 20052)^{3)}$ と, 回 路構成を簡素化し $100 \mathrm{MHz}$ という高速化を達成した 10 ビット DA コンバーター $(\mathrm{CX} 20051 \mathrm{~A})^{4)}$ を開発し た.これらのコンバーターは汎用のバイポーラ標準プ ロセスを使用し素子数が大幅に低減できたため歩留り も高く, 高速 $\mathrm{AD} / \mathrm{DA}$ コンバーターのローコスト化 への道が開かれたと思われる。

故に開発したコンバーターは放送機器の研究開発技 術者，あるいは画像処理関係の技術者に大きな影響を 及ぼすものと考えられる。

本文は，コンバーターのローコスト化扔よび精度を 従来になく高められた技術に関して述べ，さらに $\mathrm{AD}$ コンバーターモジュール（BX 1200）についても言及す る。

$\dagger$ †ニー株式会社 半導体事業本部

"Low Cost AD/DA Converters for TV" by Takeshi Matsushita (Semiconductor Group, SONY Corporation, Atsugi)

$462(24)$

\section{2. 高速 $\mathrm{AD}$ コンバーターの変換方式}

\section{1 並列形}

通常のテレビ信号のディジタル化では，サンプル周 波数が $20 \mathrm{MHz}$ で 8 ビットの分解能があれば一応充 分な画質が得られると考えられていで $\mathrm{AD}$ コンバーターの代表的方式は並列比較である ${ }^{6}$.

並列形 $\mathrm{AD}$ コンバーターは図 1 に示すように, $n$ ビットの場合には $\left(2^{n}-1\right)$ 個の比較器, $2^{n}$ 個の抵抗列 とエンコーダーにより構成される．画像処理として例 えば 8 ビットを用いる時には 255 個の比較器が必要と なる。

この方式では, 入力にアナログ信号 $V_{i n}$ が印加さ れると各比較器は瞬時に判定を行い, 比較器出力は工 ンコーダーを通してディジタルコードに変換し出力さ れる. 変換時間は比較器の伝搬遅延とセトリング時間 によりほぼ決定されるため, 高速変換が可能である.

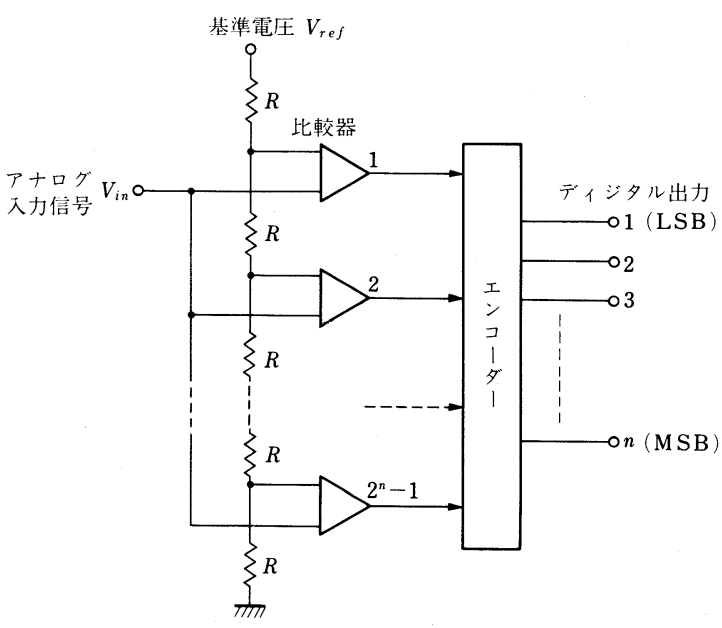

図 1 並列形 $\mathrm{AD}$ コンバーターの構成 テレビジョン学会誌 Vol. 37, No. 6 (1983) 
並列形は上述のように $\left(2^{n}-1\right)$ 個の比較器が必要な ため, 高分解能を得ようとして分解能を 1 ビット増加 する毎に約 2 倍の回路規模になる. 10 ビット並列形 $\mathrm{AD}$ コンバーターでは約 4 万素子という回路規模の LSIになってしまう7).

並列形は比較器を並列に並べるだけの簡単なものの ように考えられるが, モノリシック化のためには, 同 性能の比較器およびリファレンス用の抵抗をチップ上 に広い範囲にわたって精度良く実現しなければならな い.このため, パターン設計拉よびプロセスパラメー ターの制御にかなりのノウハウが必要とされる。ま た，基本的に素子数が多いこと，および入力に多数の 比較器が並列に接続されることから, 消費電力と入力 容量が大きなものになる ${ }^{6}$.

故に, 並列形 $\mathrm{AD}$ コンバーターの低消費電力化等 の高性能化を図るには, 先端の微細加工技術が必須条 件となる。微細加工技術を支える各種の装置は高価格

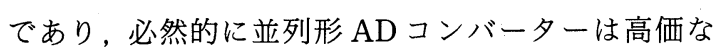
ものになる.

\section{2 直並列形}

直並列形 $\mathrm{AD}$ コンバーターは図 2 に示すように $\mathrm{AD}$ 変換を 2 段に分割して行う方式であり， 8 ビットの例 で示すと, サンプルホールド（S/H）回路にてホール ドされたアナログ入力信号のレベルは，まず最初の並 列形 4 ビット $\mathrm{AD}$ コンバーターで変換され上位 4 ビ ットのディジタル出力を得る. 同時に, このディジタ ル出力は DA 変換されアナログ信号に戻し, この上 位 4 ビットに相当するアナログ信号と, 入力でホール ドされたレベルとの差を次段の並列形 4 ビット $\mathrm{AD}$ コンバーターで $\mathrm{AD}$ 変換し, 下位の 4 ビットのディ ジタル出力を得る.

この方式では, 比較器の数は $\left(2^{4}-1\right) \times 2=30$ 個で すむため, 8 ビット並列形と比較して回路規模は極端 に縮少する。しかしながら,この方式は上位, 下位に 分けて 2 回の $\mathrm{AD}$ 変換を行うことから変換時間が長

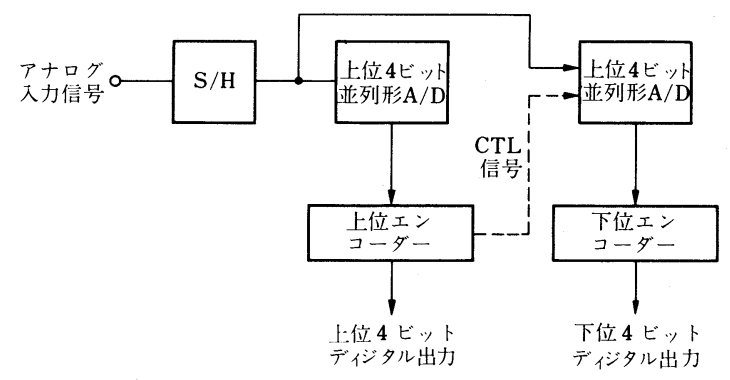

図 3 新直並列形 8 ビット $\mathrm{AD}$ コンバーターの構成

くなること, 下位ビット変換時に入力アナログ信号の レベルが変動しないように $\mathrm{S} / \mathrm{H}$ 回路が必要になるこ と, また図 2 に示した 4 ビット DA コンバーターと 減算器は共に 8 ビット相当の精度が必要であること等 が欠点となる。

高精度の減算器をモノリシック化することが容易で ないため, いままで直並列形では 7 ビットがモノリシ ック化されたにすぎないる

\section{3 新直並列形}

新直並列形 $\mathrm{AD} コ$ コン゙ーターは, 基本的には前項 の直並列形と同様に上位, 下位ビットに分けて $\mathrm{AD}$ 変換を行い比較器の減少を図ったものであるが, 図 3 に示すように, DA コンバーターと減算器を必要とし ないことがこの方式の最大の特長である.すなわち $\mathrm{S} / \mathrm{H}$ 回路でホールドされた入力レベルは, まず上位 4 ビット AD 交換されるが, 上位エンコーダーから CTL 信号が出て下位 $\mathrm{AD}$ コンバーターを動作させる のがこの方式である.

基本動作原理をわかりやすく説明するため, 図 4 に 示すように上位 2 ビット, 下位 2 ビットの計 4 ビット の場合で示すと, 回路は上位下位それぞれ 3 個の比較 器, $\mathrm{S}_{1} \sim \mathrm{S}_{4}$ のスイッチ列, 16 分割された 1 本から構 成された抵抗列およびエンコーダーにより構成され る.

$\mathrm{S} / \mathrm{H}$ 回路によりホールドされた入力レベル $V_{i n}$ は 上位比較器により $V_{r e f}(T) \sim V_{1}, V_{1}$

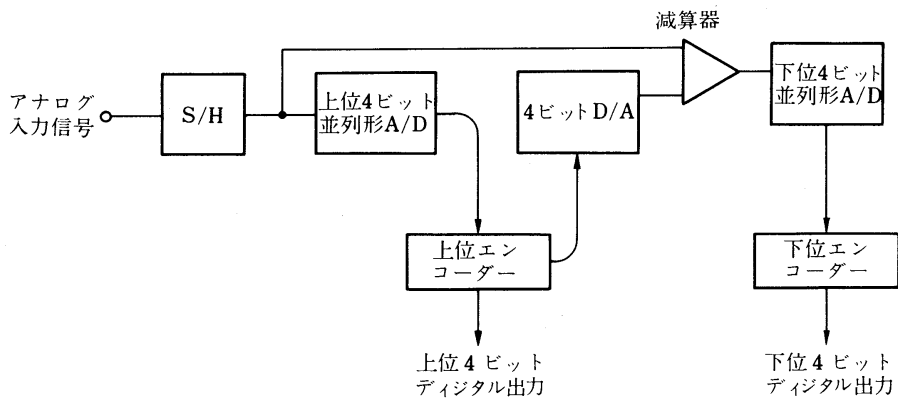

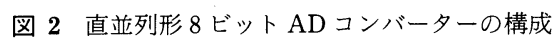
$\sim V_{2}, \quad V_{2} \sim V_{3}, \quad V_{3} \sim V_{\text {ref }}(B)$ のどのレ ベルにあるか判定される. 判定結果は上 位エンコーダーを介して上位 2 ビットの ディジタル出力に変換される. 同時に $V_{\text {in }}$ のレベルに従って $\mathrm{S}_{1} \sim \mathrm{S}_{4}$ のスイッ チ列の 1 列がオンされる.スイッチオン により下位比較器にリファレンス電圧が 与えられ， $\left(V_{r e f} / 4\right)$ の間で細かい比較 判定が行われ，下位エンコーダーを通し て下位 2 ビットの出力を得る. 


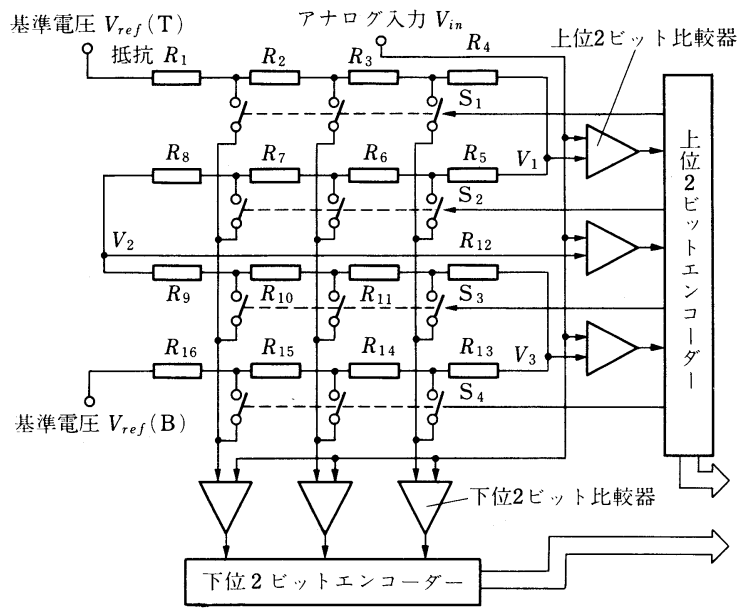

図 4 新直並列形動作原理（4ビットの場合）

この方式は，抵抗ストリングとして上位と下位に共 通に同じものを使用するので単調性が確保できる．さ らに, この方式では比較器の数が少ないので, 比較器 の入力バイアス電流が少なく, 直線性誤差が小さくな る. また入力容量も比較器の数が少ないため小さくな るという利点がある。

\section{3. 新直並列形 8 ビット $\mathrm{AD}$ コンバーター}

新直並列形を採用した 8 ビット $\mathrm{AD}$ コンバーター （CX 20052）のブロック図を図 5 に示す. S/H 回路で ホールドされた入力レベル $V_{\text {in }}$ が 21 ピンに与えら れ，そこで上位 4 ビット分の $\mathrm{AD}$ 変換がなされる. 引き続き入力レベルはマトリクス回路に加えられ, マ
トリクス回路を経て下位比較器によって 下位 4 ビット分が $\mathrm{AD}$ 変換される. 比 較器に後続のエンコーダー, 出力バッフ アーを通してディジタル出力が得られ る.

CX 20052 のマトリクス回路を構成す るスイッチブロックは, 下位比較器の初 段部分を兼ねた差動アンプになってい て，わずか 3 個のトランジスタで構成し ている．故に，マトリクス回路は 8 ビッ トの場合には 720 個で構成できる。

一方, 並列形 8 ビットの場合には, 255 個の比較器で構成されるので, 比較 器が仮りに 20 素子で構成できるとして も 5100 素子数が必要となる. マトリク ス部では抵抗ストリングと比較器とを密接に配置し, かつ抵抗ストリングの精度を得るように工夫しなくて はならないが，直並列形では素子数が並列形と比べて 約 $1 / 7$ となり，パターン配置が極めて容易であり，ま た抵抗ストリングの線幅は並列形と異なり全体にわた って同一にできる。このため抵抗ストリングのエッチ ング幅のばらつきが精度に影響を及ぼさず，プロセス が変動しても精度は充分に確保できる。

CX 20052 は, 新直並列方式の採用により 8 ビット においてもわずか 2300 素子で構成でき, 従来の並列 形 8 ビット $\mathrm{AD}$ コンバーター(約 17000 素子 $)^{6)}$ に比較 して $1 / 7$ になったため, 先端の微細加工技術は必ずし も用いる必要はなくなった。ただし CX 20052 は外部

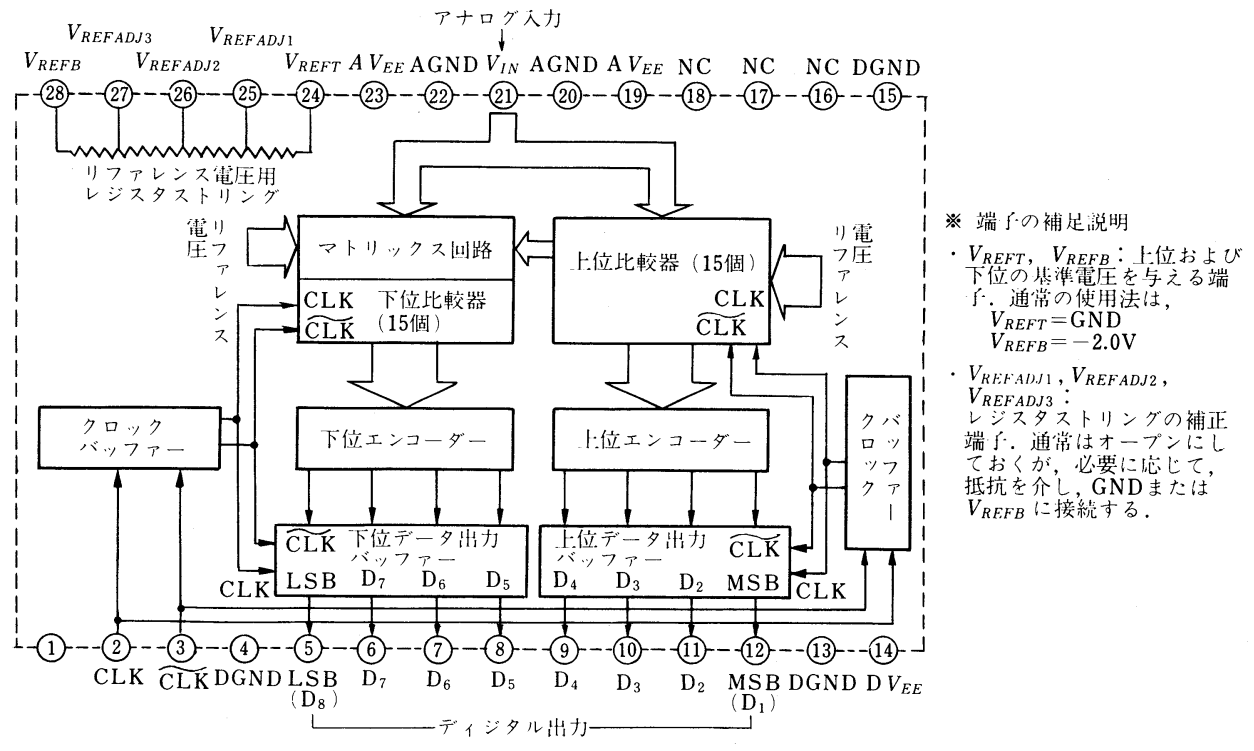

図 5 CX 20052 のブロック図 
に $\mathrm{S} / \mathrm{H}$ 回路を必要とし, 並列形 $\mathrm{AD}$ コンバーターの 機能をすべて含んでいるわけではない.

\section{10 ビット DA コンバーター}

高速 DA コンバーターの変換方式は大きく, (1) R$2 \mathrm{R}$ 抵抗ラダー形, (2)重み付け電流切り換え形, (3)電 流加算形，の 3 つに分けられる.

R-2 R 抵抗ラダー形は，抵抗とトランジスタとで定 電流源を構成するため, これらの特性のばらつきが精 度に影響を与えるのが難点で, 上位ビット側ほど精度 に与える影響は大きい。重み付け電流切り換え形は, 電流源とスイッチのペアが 1 ビット分に対応してい て, 各電流源の比率が正確でなくてはならず，特に上 位ビット側ほど精度が要求される。電流加算形は, 各 電流のばらつきが精度に与える影響はラダー形に比べ て小さくなる利点を有するが， $n$ ビットの場合 $\left(2^{n}\right.$ -1) 個の電流源とスイッチを必要とするため, 回路規 模が大きくなるという欠点がある.

今回開発した 10 ビット DA コンバーター (CX 20051A）は, 上位 4 ビットを電流加算形, 下位 6 ビッ 卜を $\mathrm{R}-2 \mathrm{R}$ 抵抗ラダー形とし，ラダー形の精度面での 欠点を電流加算形で補っている。また，ラダー形を用 いることにより, 電流加算形で 10 ビット構成する場 合よりも回路規模は極端に小さくなっている.

CX 20051A のブロック図を図6に示すが，上位 4 ビットのディジタル入力はデコーダーを通して電流加 算形の電流源スイッチを作動させ, 下位 6 ビット分に ついては状態に応じて直接ラダー形の電流スイッチを 切り換える. 回路方式には ECL を採用して高速性を
得るようにし，またローコスト化するため，上位 4 ビ ットデコーダーの回路構成を工夫し ${ }^{4)}, 820$ 素子にま とめることができた .

\section{5. ウエハープロセスと特性}

上述した $\mathrm{AD} / \mathrm{DA}$ コンバーターは，それぞれ 2300 ， 820 素子という少ない素子数で構成できるので, 先端 の微細加工技術を必ずしも用いる必要はない. 今回口

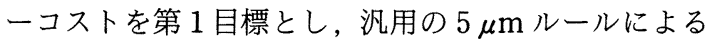
バイポーラ標準プロセス ${ }^{9)}$ を用いて CX 20052 とX $20051 \mathrm{~A}$ を開発した。両 ICとも ECL 構成をとり 1.5 $\mathrm{GHz}$ の $f_{T}$ を有する $n p n$ トランジスタと抵抗のみで 設計されていて，2 層配線を使用している.

CX 20052 の抵抗ストリングは, 精度を上げるため $35 \mu \mathrm{m}$ の幅の $\mathrm{Al}$ 線を用いている. 比較器を構成する 2 対のトランジスタのエミッターサイズは, ベース・ エミッター間電圧差 $\left(\Delta V_{B E}\right)$ のばらつきを小さくし， 比較器のオフセット電圧を小さくするため $10 \times 10$ $\mu \mathrm{m}^{2}$ を用いた。ウエハープロセスは 10 枚という少な いマスク数ですみ, チップサイズも CX 20052 では 3. $95 \times 5.35 \mathrm{~mm}^{2}, \mathrm{CX} 20051 \mathrm{~A}$ は $2.6 \times 3.06 \mathrm{~mm}^{2}$ という 小さなサイズになった. CX 20052 のチップを写真 1 に示す.

CX 20052 の特性は, 表 1 に示すように一 $5 \mathrm{~V}$ 単一 電源で分解能 8 ビット, 最高動作クロック周波数 30 $\mathrm{MHz}$, 入力容量 $100 \mathrm{pF}$, 消費電力 $700 \mathrm{~mW}, \mathrm{DG} \cdot \mathrm{DP}$ は写真 2 に示すようにそれぞれ $0.7 \%, 0.3^{\circ}$ という良 好な值を得ている。

CX 20051 A の特性も, 表 2 に示すように一 $5 \mathrm{~V}$ 単

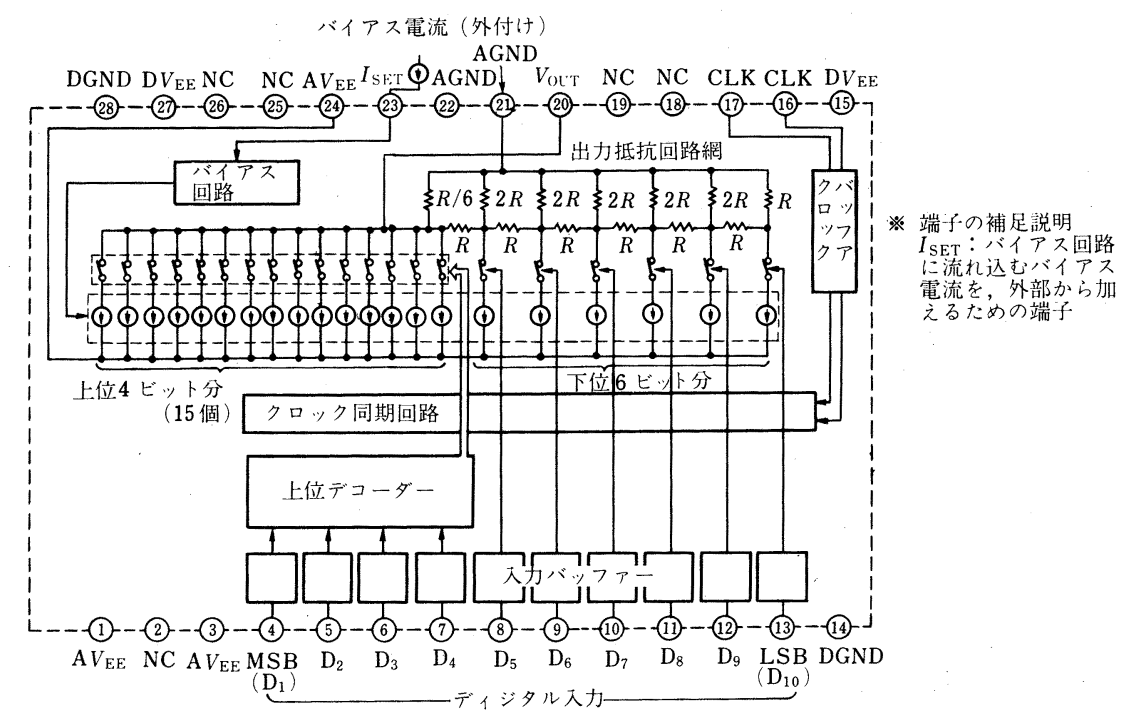

図 6 CX 20051A のブロック図 


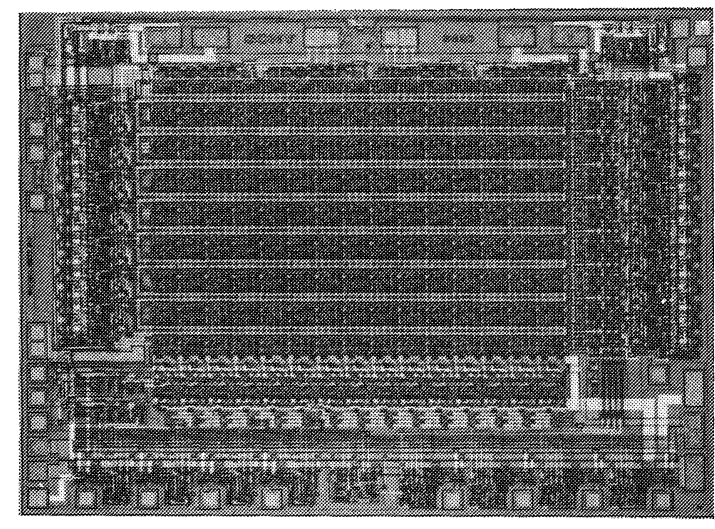

写真 1 CX 20052 のチップ写真
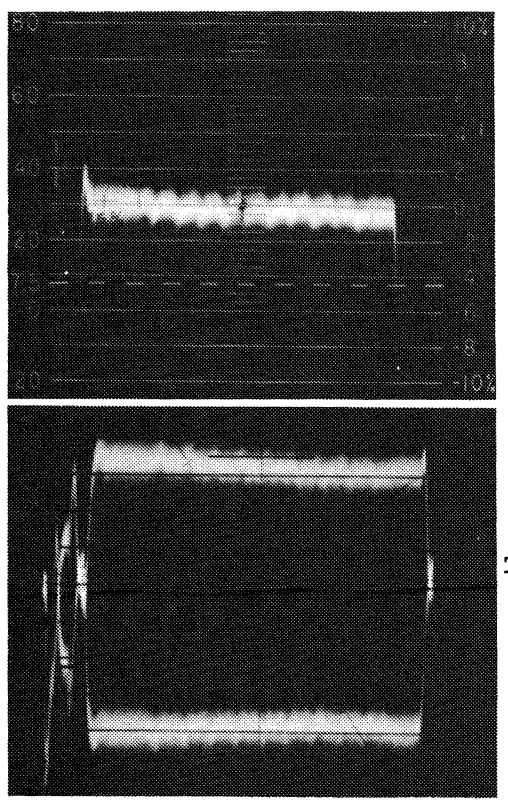

写真 2

$\mathrm{CX} 20052$ の $\mathrm{DG}$ (上)

と $\mathrm{DP}($ 下)

(ビデオ信号 : 40IRE, MOD, RAMP, クロック周波数： $20 \mathrm{MHz}$ )

表 1 CX20052(AD コンバーター)の特性

\begin{tabular}{|c|c|}
\hline 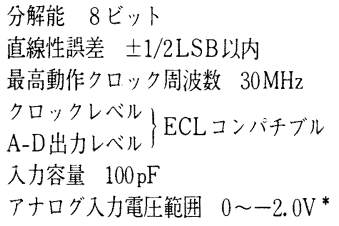 & 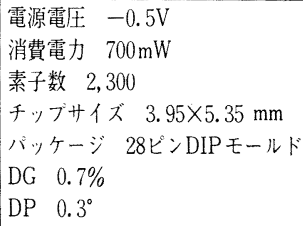 \\
\hline
\end{tabular}

*アナログ入力電圧とディジタル出カコードとの対応（アナログ入 カー2.0Vフルスケール)

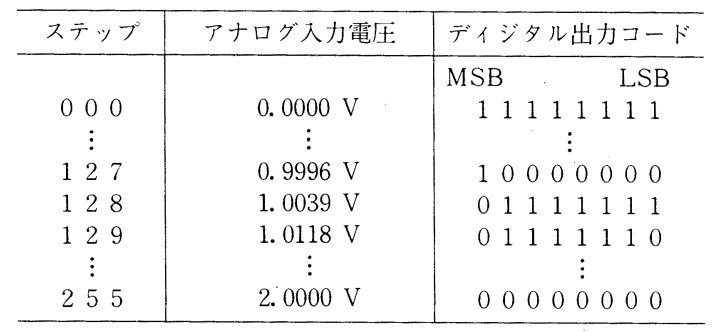

表 2 CX20051A(DA コンバーター)の特性

\begin{tabular}{|c|c|c|c|}
\hline \multicolumn{2}{|c|}{ 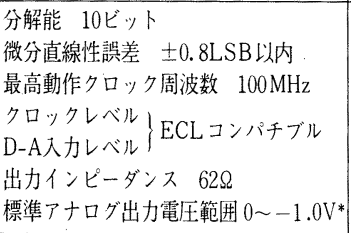 } & \multicolumn{2}{|c|}{ 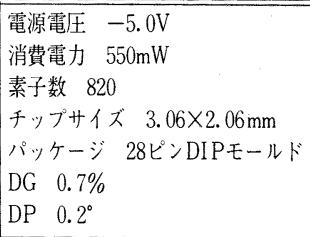 } \\
\hline \multicolumn{4}{|c|}{$\begin{array}{l}\text { *ディジタルスカコードとアナログ出力電圧との対応 (アナログ出 } \\
\text { カー } 1.0 \mathrm{~V} フ \text { フスイールの場合) }\end{array}$} \\
\hline ステップ & ディジタル入カコ & ード & アナログ出力電力 \\
\hline $\begin{array}{cccc}0 & 0 & 0 & 0 \\
& \vdots & \\
0 & \vdots & \\
0 & 5 & 1 & 1 \\
0 & 5 & 1 & 2 \\
0 & 5 & 1 & 3\end{array}$ & 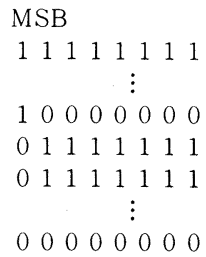 & $\begin{array}{ll}\text { LSB } \\
1 & 1 \\
& \\
0 & 0 \\
1 & 1 \\
1 & 0 \\
0 & 0\end{array}$ & $\begin{array}{c}-0.003 \mathrm{~V} \\
\vdots \\
-0.503 \mathrm{~V} \\
-0.504 \mathrm{~V} \\
-0.505 \mathrm{~V} \\
\vdots \\
1.003 \mathrm{~V}\end{array}$ \\
\hline
\end{tabular}
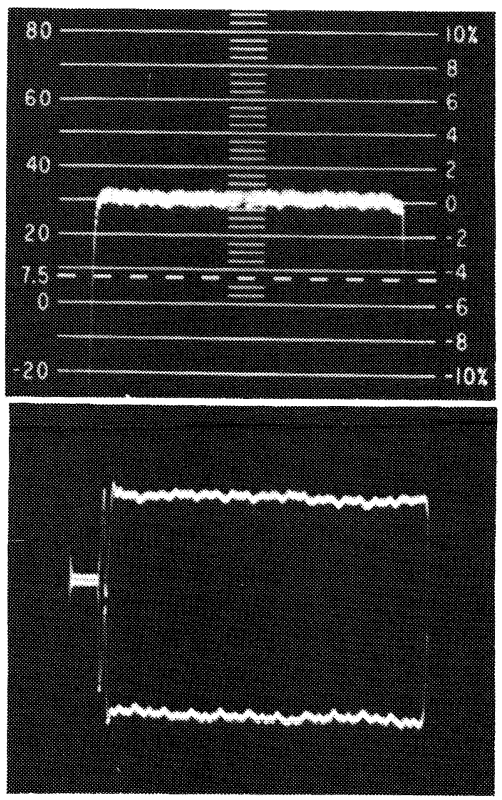

写真 3 D-A コンバーターCX 20051A の DG(上)と $\mathrm{DP}(下)$ (クロック周波数：14.3 MHz)

一電源で分解能 10 ビット, 最高動作クロック周波数 $100 \mathrm{MHz}$, 出力インピーダンス $62 \Omega$, 消費電力 550 $\mathrm{mW}, \mathrm{DG}$ ・DP は写真 3 に示すように, それぞれ 0.7 $\%, 0.2^{\circ}$ である.

\section{6. $\mathrm{AD}$ コンバーターの応用例}

CX20052 は並列形 AD コンバーターと異なり, 外 部に $\mathrm{S} / \mathrm{H}$ 回路を必要とする. S/H 回路は一般に難し い回路であると考えられているが, $30 \mathrm{MHz}$ 程度の 


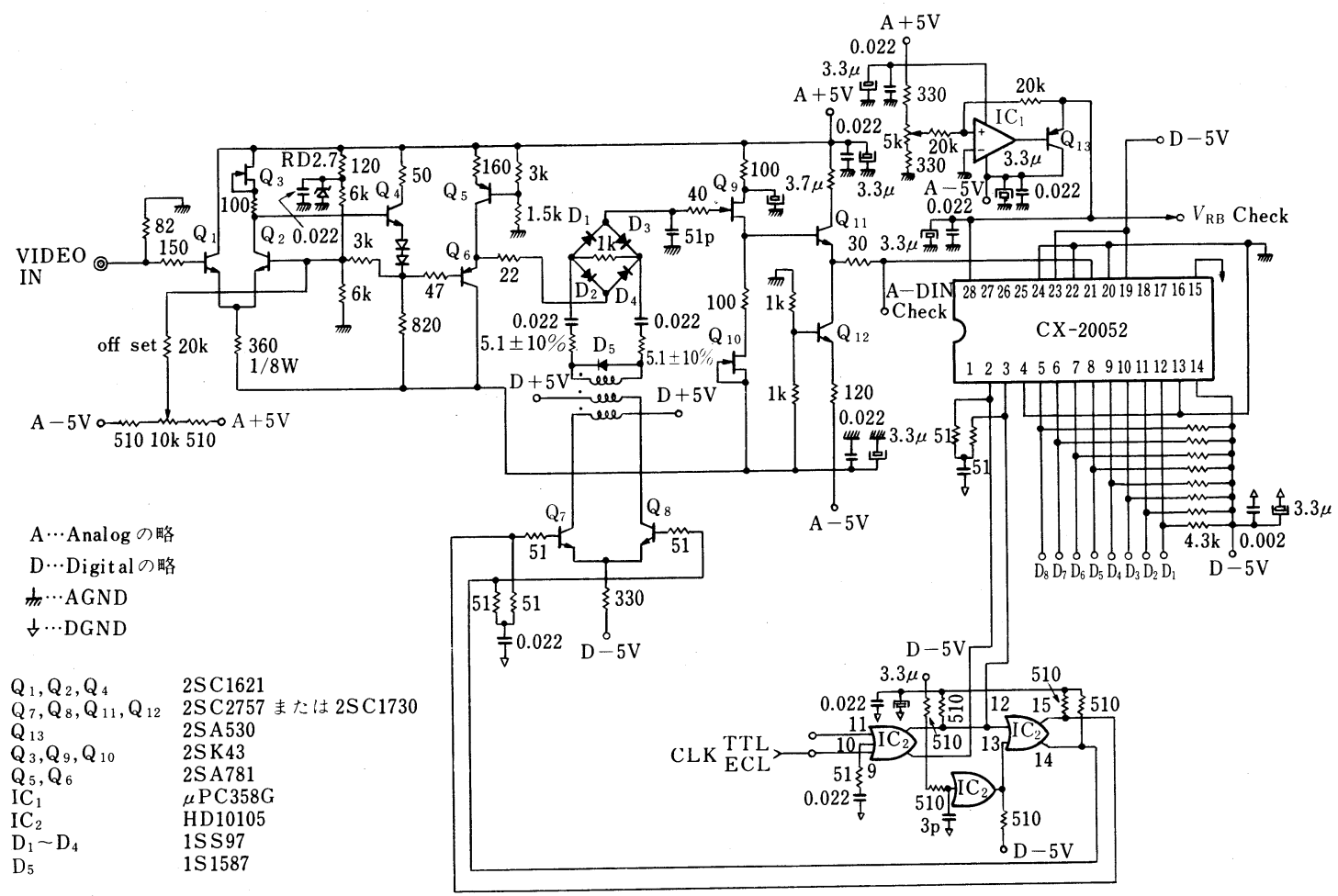

図 7 CX 20052 の応用回路例

S/H 回路は，図７に示すようにスイッチ部をダイオ ードリングで構成されたものを用いれば，比較的簡単 に，かつローコストでできる。

$\mathrm{CX} 20052$ を実際に使用するには, S/H 回路の波形 とクロックおよび $\mathrm{AD}$ 出力波形のタイミングが重要 であり, S/H 回路のアクイジションタイム等を充分 考慮したうえで夕イミングを設定する必要がある．

図 7 の応用回路をモジュールにまとめた BX 1200 がある. BX 1200 は電源電圧が $\pm 5 \mathrm{~V}$, 消費電力 1.6 $\mathrm{W}, 30$ ピン(縦 $54 \mathrm{~mm}$, 横 $77 \mathrm{~mm}$, 高さ $15 \mathrm{~mm}$ ) であ る.

新直並列形 $\mathrm{AD}$ コンバーターは, $\mathrm{S} / \mathrm{H}$ 回路を必要 とするのがひとつの欠点とされているが, チップサイ ズが $1.5 \times 2 \mathrm{~mm}^{2}$, 消費電力が $500 \mathrm{~mW}$, サンプリン グ周波数が $40 \mathrm{MHz}$ の $\mathrm{S} / \mathrm{H}$ モノリシック IC が開発 された ${ }^{10)}$. したがって, 近い将来 $\mathrm{S} / \mathrm{H}$ 回路と新直並 列形 $\mathrm{AD}$ コンバーターが 1 チップ化され, さらにロ ーコスト化が進展するものと予測される.

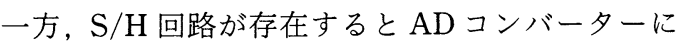
入る入力信号のスルーレートが減少するので, より高 いアナログ入力周波信号を扱うことができるようにな り, 最近脚光を浴びつつある高品位テレビ ${ }^{11)}$ 等へ応 用されていくものと考えられる.

\section{8.むす ひ}

本文では, 新直並列形 $\mathrm{AD} コ$ コバーターと, 回路 規模を縮小し回路を簡素化したDA コンバーターの 開発について述べた。両コンバーターとも素子数が大 幅に減少した結果, 先端の微細加工技術を用いること なく, 汎用のバイポーラプロセスで, チップサイズが 小さくかつ高歩留りのものが達成でき，ローコスト化 が実現された。

またローコスト AD コンバーターは, 外部回路を

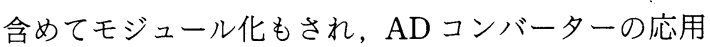
技術者の注目を浴びると思われる。これらの成果によ りディジタルテレビ等, 民生機器のディジタル化が到 来する時期がより近づいたように考えられる.

新直並列形 $\mathrm{AD}$ コンバーターは今回は汎用プロセ スで行ったが, 最先端の微細加工技術を駆使すれば, $9 ， 10$ ビット等，多ビット化が容易に実現され，ま た消費電力も上で述べた值の数分の 1 になるであろ う. 故に, 新直並列形 $\mathrm{AD}$ コンバーターは, テレビ カメラを含めたトータルテレビジョンシステムのディ ジタル化に大きく貢献するものと期待している.

終りに，本執筆に関し種々の御援助をいただいた川 島混成集積回路事業部長, 青木 IC 設計部長, 竹田係 
長他，関連諸氏に深謝します。（昭和 58 年 2 月 7 日受付）

\section{〔参 考 文 献〕}

1）十楚博美：“ディジタル・オーディオのしくみと特徵”, 電子 技術，24，3，pp. 23-28（1982）

2) T. Fischer: "Digital VLSI Breeds Next-Generation TV Receivers”, Electronics, 54, 16, pp. 97-103 (Aug. 11, 1981)

3) T. Sekino, M. Takeda and K. koma: "A Monolithic 8Bit Two-step Parallel ADC without DAC and Subtractor Circuits", IEEE ISSCC Digest of Technical Papers, pp. 46-47 (1982)

4）岩佐優, 竹田仁：“ビデオ用 10 ビット D/A コンバータ”, 信学会技術研究報告, 82, 13, pp. 1-8（1982）

5）森下政信：“ディジタルカメラ”, テレビ誌， 36, 1, pp. 3033 (1982)
6) J. G. Peterson: "A Monolithic Video A/D Converter", IEEE J., SC-14, 6, pp. 932-937 (1979)

7) 井上道弘, 竹本豊樹：“高速 10 ビットA-D コンバータ”, 電子材料, 21，12，pp. 53-58（1982）

8) R. J. van De Plassche and R. E. J. Van Der Grift: "A High-Speed 7 Bit A/D Converter”, IEEE J., SC-14, 6 , pp. 938-943 (1979)

9) Y. Ueki, T. Tsuyuki, I. Nakamura, T. Inoue and $M$. Miyake: "Custom Design Oriented High Performance Bipolar Linear LSI Technology", Proc. Custom Integrated Circuit Conf., pp. 92-93 (May, 1980)

10) K. Tanaka, F. Ishikawa K. Abe and K. Koma: "A 40 $\mathrm{MHz}$ Monolithic Sample and Hold IC", IEEE ISSCC Digest of Technical Papers, pp. 190-191 (1983)

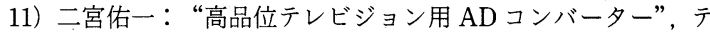
レビ誌，35，2，pp. 129-135（1981） 